\title{
A study of nerves containing peptides in the pulmonary vasculature of healthy infants and children and of those with pulmonary hypertension
}

\author{
KIM M ALLEN, JOHN WHARTON, * JULIA M POLAK, * SHEILA GHAWORTH \\ From the Institute of Child Health and ${ }^{\star}$ Royal Postgraduate Medical School, London
}

SUMMARY Nerves containing peptides that supply the human intrapulmonary vasculature were studied in 21 controls aged one month to 24 years and in 13 patients with pulmonary hypertension aged 11 days to eight years. An indirect immunofluorescence technique was used to study the distribution and relative density of nerve fibres containing the general neuronal marker, protein gene product 9.5; tyrosine hydroxylase; synaptophysin; neuropeptide tyrosine; vasoactive intestinal polypeptide; substance $P$, somatostatin; and calcitonin gene related peptide. At all ages in normal and hypertensive lungs neuropeptide tyrosine was the predominant neuropeptide associated with the pulmonary vascular nerves. In normal lungs the relative density of nerve fibres increased during childhood only in the arteries of the respiratory unit. Pulmonary hypertension was associated with the premature innervation of these arteries during the first year of life.

Innervation of small, abnormally thick-walled pre-capillary vessels by predominantly vasoconstrictor nerves may help to explain the susceptibility of infants to pulmonary hypertensive crises.

There is no reliable effective medical treatment for pulmonary hypertension. Children with potentially reversible pulmonary vascular disease can die after a technically successful intracardiac repair because of the development of pulmonary hypertensive crises that become intractable to all forms of treatment. Pharmacolological management of pulmonary hypertension might be improved by understanding how the pulmonary vasculature is innervated in such a lung.

During normal development the wall structure of the entire pulmonary arterial tree is remodelled. Connective tissue is deposited and medial smooth muscle cells differentiate, acquiring a contractile rather than a synthetic phenotype. ${ }^{1}$ The concentration of contractile myofilaments increases and the type of cytoskeletal proteins change. ${ }^{2}$ In children with pulmonary hypertensive congenital heart disease these changes are accelerated or abnormal. ${ }^{3}$ The relation between remodelling of the pulmonary arteries and pulmonary innervation in the human lung is unclear. In the normal immature pig lung differentiation of smooth muscle cells is accompanied

Requests for reprints to Professor Sheila G Haworth, Institute of Child Health, 30 Guilford Street, London WC1N 1EH.

Accepted for publication 27 July 1989 by an increase in the density of presumed sympathetic nerves. ${ }^{4}$ Experimental studies showed trophic interactions between sympathetic nerves and vascular smooth muscle cells. ${ }^{5}$

The adult human pulmonary vasculature is innervated by noradrenergic and cholinergic nerves ${ }^{67}$ but these nerves also contain other putative transmitters, including several vasoactive peptides, which may have a regulatory role in the pulmonary circulation. Examples of such peptides identified in mammalian pulmonary nerves include vasoactive intestinal polypeptide ${ }^{8}$ (predominantly in parasympathetic nerve fibres), substance $P$ and the neurokinins ${ }^{9}$ and calcitonin gene related peptide ${ }^{10}$ (all present in sensory nerve fibres), and neuropeptide tyrosine $^{11}$ (in sympathetic fibres) as recently reviewed by Lundberg et al. ${ }^{12}$

We used immunocytochemical techniques to examine the innervation of the pulmonary vasculature in the normal and pulmonary hypertensive human lung. The overall pattern of innervation was studied with an antiserum to general neuronal cytoplasmic marker, protein gene product $9 \cdot 5$. Specific subpopulations of nerve fibres were identified by antibodies to neuropeptides and to the enzyme tyrosine hydroxylase which synthesises catecholamines. 


\section{Patients and methods}

The innervation of the intrapulmonary arteries and veins and the bronchial arteries was examined at necropsy in 18 children and three adults without cardiopulmonary disease and in 13 children who had pulmonary hypertension (table 1). In 11 children, pulmonary hypertension was caused by congenital heart disease and two had primary idiopathic pulmonary hypertension of the newborn. Lung tissue was obtained less than 24 hours after death. Blocks of tissue $\left(1 \mathrm{~cm}^{2} \times 0.5 \mathrm{~cm}\right)$ were dissected out from the hilum to the periphery to include airways and their associated arteries so that elastic, large and small muscular arteries were samples in addition to the alveolar region of the lung. Tissue blocks were fixed overnight (9-12 hours) at $4^{\circ} \mathrm{C}$ in a modified Bouin's solution. ${ }^{4}$ After the tissue was rinsed in several changes of phosphate buffered saline $(0.1 \mathrm{~mol} / \mathrm{l}$, $\mathrm{pH} 7 \cdot 2$ ) containing $15 \%(\mathrm{w} / \mathrm{v})$ sucrose and $0 \cdot 1 \%$ sodium azide, cryostat blocks were prepared and stored in liquid nitrogen. Transverse cryostat sections ( $15 \mu \mathrm{m}$ thick) were collected on glass slides coated with poly-L-lysine and allowed to dry for an hour at room temperature. Before immunostaining by the indirect immunofluorescence technique, sections were immersed in phosphate buffered saline containing $0.2 \%$ Triton $\mathrm{X}-100$ for an hour at room temperature, rinsed in phosphate buffered saline, then counterstained with pontamine sky blue (BDH Chemicals) to reduce background autofluorescence.

The innervation was shown with primary antisera $^{13}$ to general neuronal markers and specific neuropeptides (table 2). The general neuronal cytoplasmic marker protein gene product 9.5 occurs in all peripheral nerves and in all regions of the neurone. ${ }^{14}$ Synaptophysin is a membrane protein specifically associated with small secretory vesicles thought to contain the classic neurotransmitters in nerve terminals. ${ }^{15}$ Antisera to both the sequences flanking the active and carboxy terminals of the neuropeptide tyrosine precursor molecule were used and have been shown to have an identical distribution pattern. ${ }^{16}$

Table 1 Data on 21 controls and 13 infants and children with pulmonary hypertension

\begin{tabular}{lllll}
\hline Controls & & & \multicolumn{2}{l}{ Pulmonary hypertension } \\
\cline { 5 - 5 } Age & No & & Age & No \\
\hline 1 mnth & 3 & & 11 days & 1 \\
2 mnths & 2 & & 2 mnths & 3 \\
3 mnths & 2 & & $6-10$ mnths & 2 \\
4 mnths & 2 & & $1-1.5$ yrs & 3 \\
$9-10$ mnths & 2 & & $2 \cdot 5-3 \cdot 5$ yrs & 3 \\
$1-1 \cdot 5$ yrs & 3 & & 8 yrs & 1 \\
$2 \cdot 5-3 \cdot 5$ yr & 4 & & \\
Adult & 3 & & & \\
\hline
\end{tabular}

Tachykinin-like immunoreactivity was shown with antibodies raised to substance $P$ but which cross react with the neurokinins $A$ and $B$. Sections were incubated with fluorescein isothiocyanate-conjugated sheep anti-rabbit IgG (Wellcome Diagnostics) for an hour at room temperature. After a further rinse in phosphate buffered saline, sections were mounted in phosphate buffered saline/glycerol. Controls included the application of pre-immune serum as first layer and diluted primary antisera preabsorbed with peptide $\left(1-20 \times 10^{-6} \mathrm{~mol} / \mathrm{l}\right)$. Tissue sections were examined by a fluorescence microscope (Olympus Vanox AH-2).

We checked that the pulmonary vasculature in those who died without cardiopulmonary disease was indeed normal. Therefore blocks of tissue from areas of the lung adjacent to those used for the immunofluorescence study were prepared for light microscopical examination after staining with haematoxylin and eosin and with Miller's elastin stain counterstained with van Geison's stain. The percentage arterial medial thickness $(2 \times$ medial thickness divided by external diameter) in arteries of different sizes and the external diameter of arteries within the respiratory unit was determined and the findings were compared with those of a previous extensive light microscopical study of normal pulmonary arterial development. ${ }^{17}$

\section{Results}

FEATURES COMMON TO ALL THOSE EXAMINED AT ALL AGES

Intrapulmonary arteries

The distribution of nerves accompanying the pulmonary arteries was assessed by the general neuronal marker, protein gene product $9 \cdot 5$. Immunoreactivity was seen in nerve trunks and single varicose fibres or fascicles (figs 1 and $2 a$ and $b$ ). Nerve trunks containing preterminal axons were found in the mid-outer adventitia of arteries proximal to the respiratory unit.

Table 2 Antisera used to test for peptides in nerves

\begin{tabular}{lcc}
\hline Antiserum to: & Code & Dilution \\
\hline General neuronal markers: & & \\
Protein gene product 9.5 & 1648 & $1: 600$ \\
Synaptophysin & 1623 & $1: 800$ \\
Specific neuropeptide subtypes: & & \\
Neuropeptide tyrosine (NPY) & 1086 & $1: 400$ \\
C-flanking peptide of NPY & 1411 & $1: 600$ \\
Vasoactive intestinal peptide & 652 & $1: 2000$ \\
Somatostatin & 1082 & $1: 400$ \\
Substance P & 910 & $1: 500$ \\
Calcitonin gene related peptide & 1208 & $1: 200$ \\
Atrial natriuretic peptide (1-28) & 1607 & $1: 200$ \\
Tyrosine hydroxylase & 1731 & $1: 100$ \\
\hline See ${ }^{13}$ for further characterisation of these antisera.) &
\end{tabular}




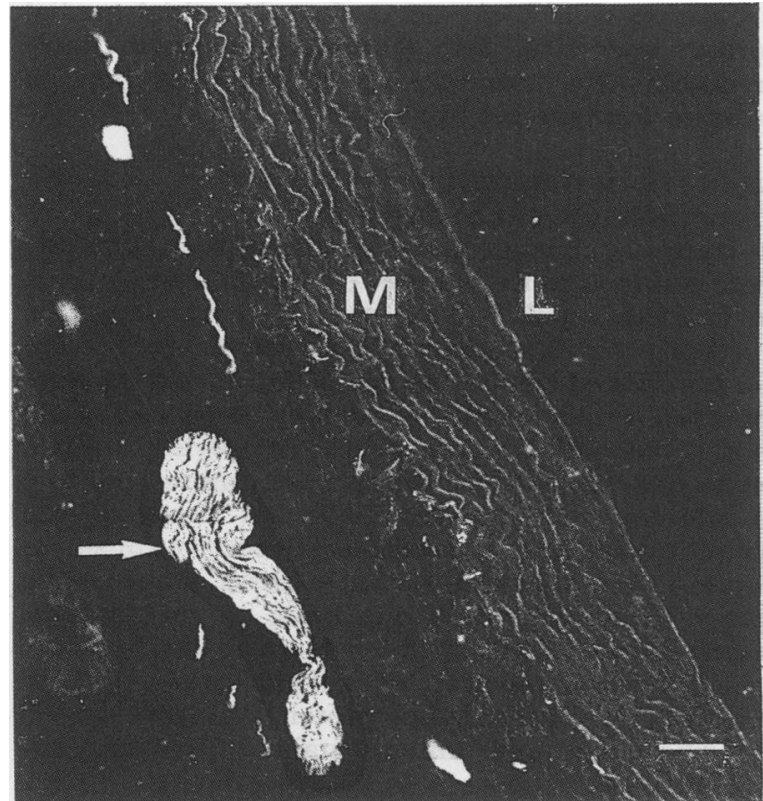

Fig 1 Photomicrograph of transverse section of an elastic intrapulmonary artery showing nerve trunks in the adventitia (arrow) that are immunoreactive for protein gene product 9.5. L, lumen; $M$, media. Scale bar $=50 \mu \mathrm{m}$.
They ran mainly parallel to the vessels and decreased in size and number from the hilum. Single, mainly varicose, nerve fibres and fascicles occurred predominantly at the adventitial-medial border and in the inner part of the adventitia in all arteries. No nerve fibres were seen within the media of small muscular arteries and only rarely penetrated into the outermost lamellar unit of elastic arteries. Nerve fibres were never seen accompanying arteries within the alveolar wall.

Most of the nerve fibres immunostained for protein gene product $9 \cdot 5$ seemed to be sympathetic in origin, showing both tyrosine hydroxylase (fig 2a and b) and neuropeptide tyrosine immunoreactivity (fig 3). Subpopulations of nerves showing immunoreactivity for other neuropeptides were far less common, fibres immunostained for vasoactive intestinal peptide being the most abundant of these. Immunostaining for vasoactive intestinal peptide was localised in fine, sparsely distributed varicose fibres, most commonly associated with small muscular arteries immediately proximal to the respiratory unit (fig 4). These nerves were occasionally seen with elastic and respiratory unit arteries. Varicose fibres that were immunoreactive for calcitonin gene related peptide were common in the nerve trunks but not elsewhere (fig 5). Somatostain-like and tachykinin-like immunoreactive fibres were rare in all types of artery.
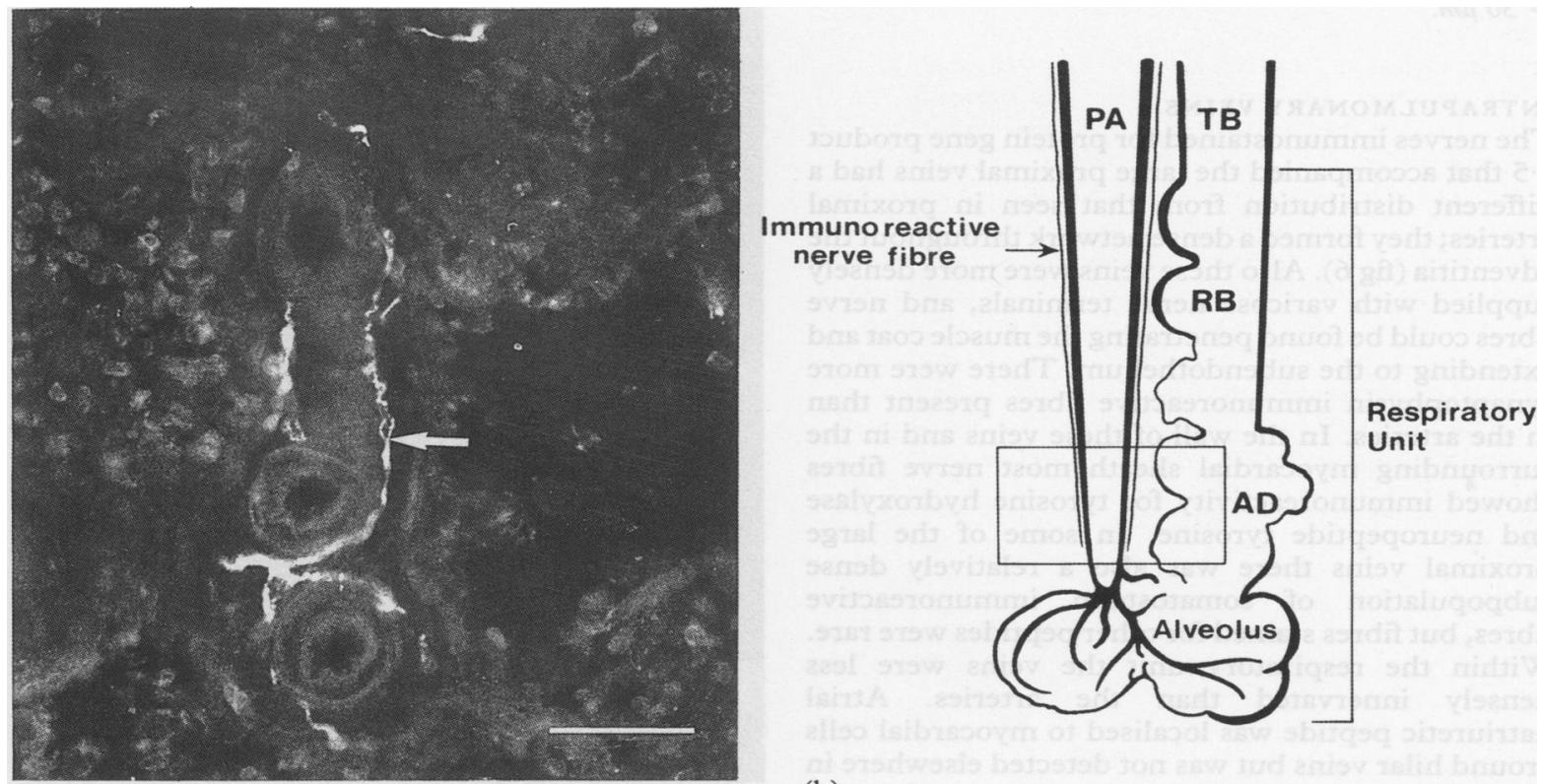

(b)

Fig 2 (a) Tyrosine hydroxylase immunoreactive perivascular nerve fibres (arrow) at the adventitial-medial border of an alveolar duct artery in a child aged two and a half. Scale bar $=50 \mu \mathrm{m}$. (b) Diagram of terminal bronchiolus (TB) and airways of respiratory unit accompanied by an innervated pulmonary artery $(P A)$. RB, respiratory bronchiolus; $A D$, alveolar duct. Square indicates area shown in $(a)$. 


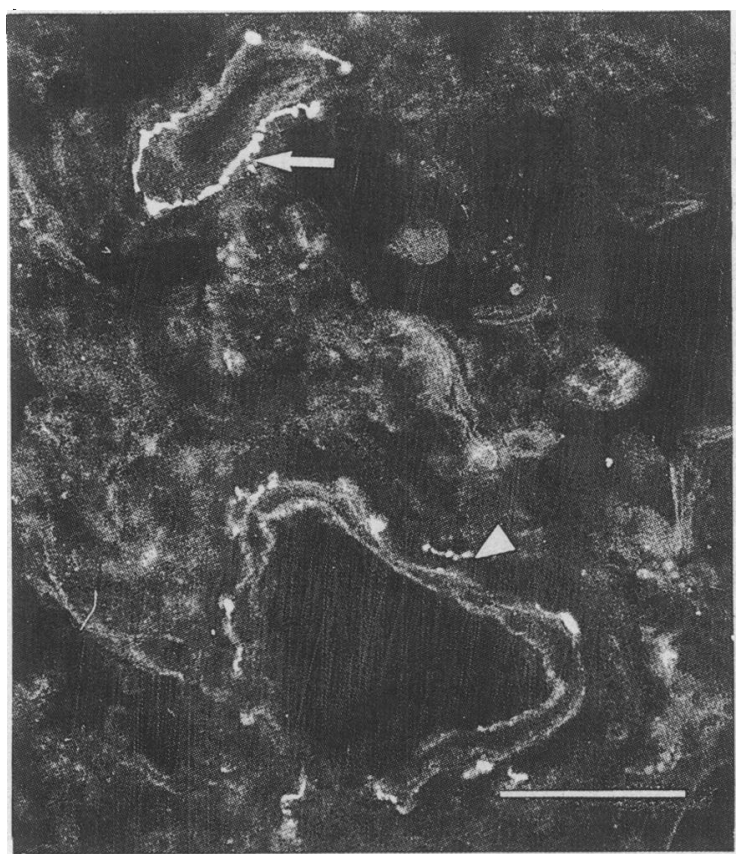

Fig 3 Photomicrograph showing nerve fibres expressing neuropeptide tyrosine immunoreactivity accompanying an alveolar duct artery (arrow) and respiratory bronchiolar artery (arrowhead) in a three month old child. Scale bar $=50 \mu \mathrm{m}$.

\section{INTRAPULMONARY VEINS}

The nerves immunostained for protein gene product 9.5 that accompanied the large proximal veins had a different distribution from that seen in proximal arteries; they formed a dense network throughout the adventitia (fig 6). Also these veins were more densely supplied with varicose nerve terminals, and nerve fibres could be found penetrating the muscle coat and extending to the subendothelium. There were more synaptophysin immunoreactive fibres present than in the arteries. In the wall of these veins and in the surrounding myocardial sheath most nerve fibres showed immunoreactivity for tyrosine hydroxylase and neuropeptide tyrosine. In some of the large proximal veins there was also a relatively dense subpopulation of somatostatin immunoreactive fibres, but fibres stained for other peptides were rare. Within the respiratory unit the veins were less densely innervated than the arteries. Atrial natriuretic peptide was localised to myocardial cells around hilar veins but was not detected elsewhere in the lung.

\section{Bronchial arteries}

Nerves accompanying the arteries of the systemic circulation were localised at the adventitial-medial $C$. border and like the pulmonary arteries were $\overrightarrow{\vec{s}}$ predominantly immunoreactive for neuropeptide $\stackrel{?}{0}$ tyrosine and tyrosine hydroxylase.

\section{CHANGES IN NERVE SUBTYPE AND}

\section{DISTRIBUTION RELATED TO AGE}

In controls, changes in nerve distribution with age $\&$ were confined to the arteries of the respiratory unit. $\overrightarrow{0}$ In children aged 1-4 months, approximately one $\overrightarrow{-}$ third of arteries accompanying alveolar ducts were $\tilde{\omega}_{\tilde{N}}$ not innervated but by the age of 2.5 almost all were $\supset$ innervated and in adulthood they were invariably innervated. While most nerves supplying arteries ? accompanying alveolar ducts were immunoreactive $\stackrel{\omega}{\omega}$ to protein gene product 9.5 and neuropeptide $O$ tyrosine, rare fibres containing vasoactive intestinal 0 peptide were also found. Nerve fibres could not be shown accompanying veins lying in the alveolar $z$ region in individuals aged 1.5 years or less. In those aged 2.5 years, however, a small proportion of these veins were accompanied by protein gene product $9.5 \overbrace{\mathbb{\Phi}}$ and fibres that were immunostained for neuropeptide tyrosine.

FINDINGS IN PULMONARY HYPERTENSION In the lungs of patients with pulmonary hypertension

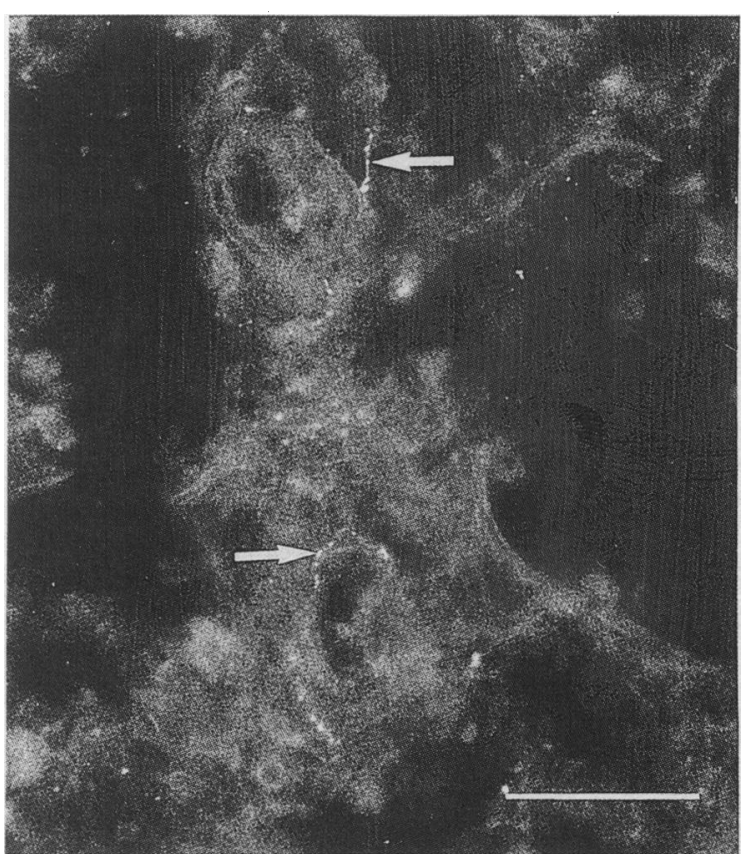

Fig 4 Photomicrograph showing varicose nerve fibres (arrows) that were immunoreactive for vasoactive intestinal peptide accompanying small muscular arteries of a three month old child. Scale bar $=50 \mu \mathrm{m}$. 


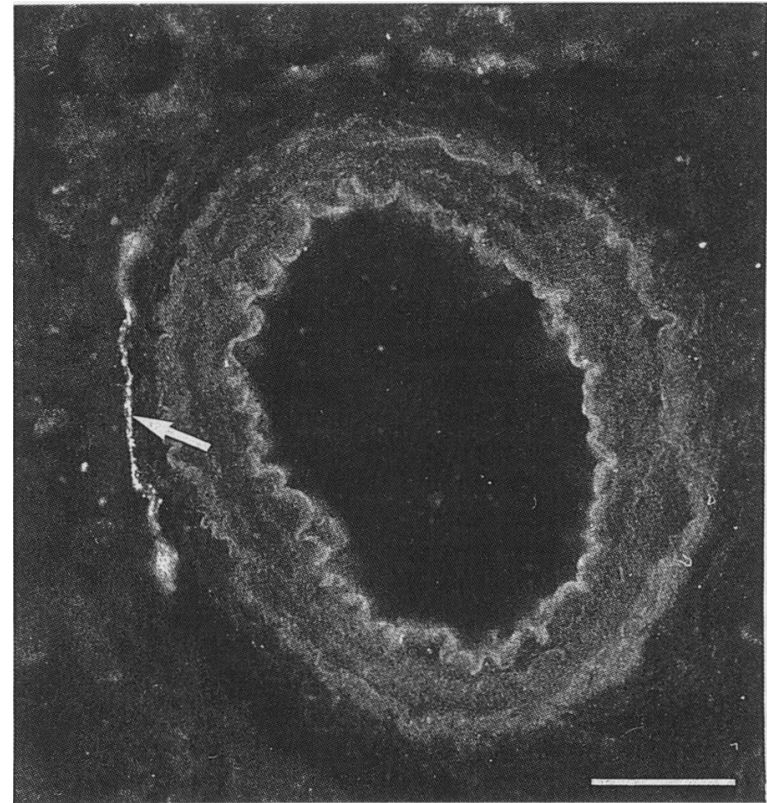

Fig 5 Photomicrograph showing nerve fibres (arrow) that were immunoreactive for calcitonin gene related peptide associated with a muscular pre-acinar artery in the lung of a two and $a$ half year old child. Scale bar $=50 \mu \mathrm{m}$.

the density and distribution of the different subpopulations of nerve fibres within arteries and veins lying proximal to the respiratory unit were similar to that in the normal individuals at all ages. Within the respiratory unit, however, in all these patients alveolar duct arteries (fig 2a) were accompanied by protein gene product 9.5 (fig 7) and nerve fibres that were immunoreactive for neuropeptide tyrosine (fig 8 ), even in those who were only 11 days old. The two patients with idiopathic persistent pulmonary hypertension also showed extension of nerves into more distal veins than was normal for their age. We found no other differences in distribution or expression of peptide immunoreactivity.

\section{Discussion}

This study showed that the innervation of the human pulmonary vasculature increases during childhood. Many arteries and veins of the respiratory unit did not have any accompanying nerve fibres in children aged 1-4 months, but the proportion of innervated vessels increased with age. This increase was more pronounced in the arterial than in the venous bed. These findings contrast with those in the pig where the distribution of nerves was as extensive at birth as in mature animals and nerve density in all arteries increased with age. ${ }^{4}$ These differences may be associated with the earlier extension of smooth muscle to more peripheral arteries and the faster differentiation of vascular smooth muscle cells in the pig. ${ }^{18}$

In the human lung, nerves supplying the large intrapulmonary arteries and veins differed in their distribution, because varicose nerve terminals were often seen penetrating the muscle coat in veins but not arteries. This may reflect a difference in the way in which the nerve stimulus is propagated in the two types of vessel. In the arteries, this may be due to diffusion of neurotransmitter across the vessel wall or to electrocoupling of the medial smooth muscle cells via gap junctions. ${ }^{1920}$ In the veins, however, the greater amount of connective tissue and fibroblasts may hinder such processes and help explain the more direct innervation of venous smooth muscle cells. Alternatively, the scarcity of nerves in the media of arteries may be related to the higher intra-arterial pressure because pressure-induced degeneration of somatic nerves has been shown in the sheep carotid artery. ${ }^{20}$

Most perivascular nerves were presumed to be sympathetic in origin in both normal and abnormal tissue at all ages. They expressed both tyrosine

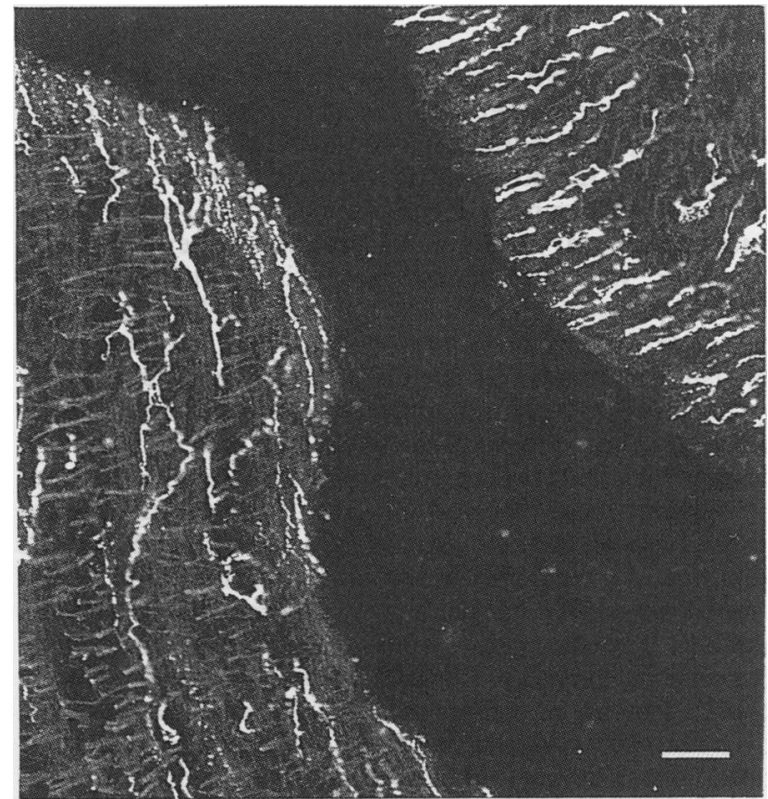

Fig 6 Photomicrograph of a large proximal vein in a two month old child showing an extensive network of fasciles and nerve fibres that were immunoreactive for neuropeptide tyrosine throughout the vessel wall. Scale bar $=50 \mu \mathrm{m}$. 


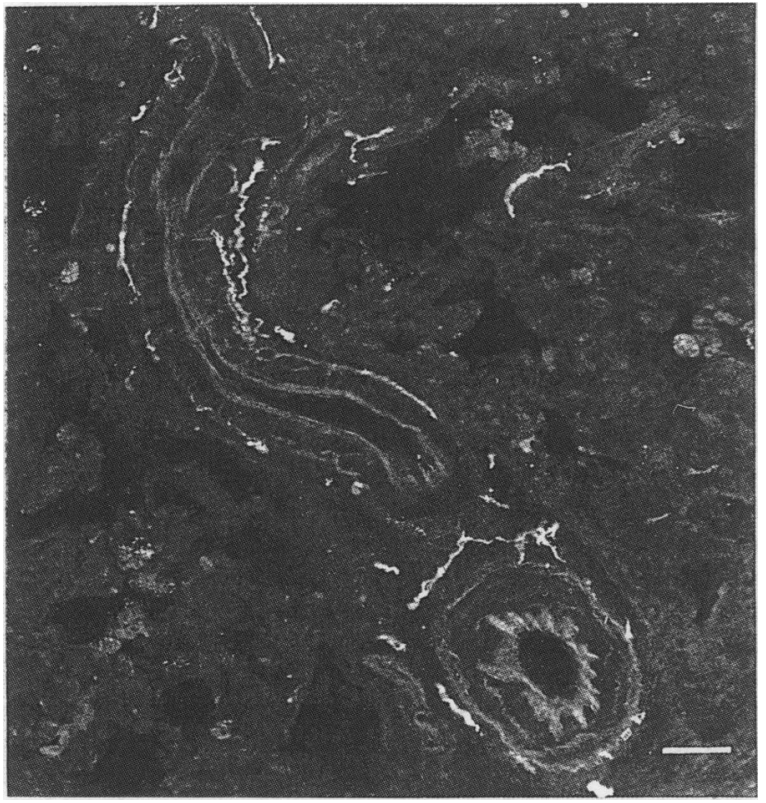

Fig 7 Photomicrograph showing nerves that were immunoreactive for protein gene product 9.5 localised to the adventitial-medial border of abnormality thick walled intraacinar arteries in a two month old child with pulmonary hypertension. Scale bar $=50 \mu \mathrm{m}$.

hydroxylase and neuropeptide tyrosine immunoreactivity. Neuropeptide tyrosine has a direct effect mediating vasoconstriction and an indirect effect modulating noradrenergic vasoconstriction via both pre and post synaptic mechanisms. ${ }^{21} 22$ In the muscular pulmonary arteries of the rabbit, neuropeptide tyrosine was found to potentiate noradrenaline evoked vasoconstriction, ${ }^{23}$ but little is known about the distribution and density of specific neuropeptide tyrosine receptors in the pulmonary vasculature.

In children with pulmonary hypertension who were less than one year old, the arteries of the respiratory unit seemed to be prematurely innervated by sympathetic-like nerve fibres. Associated changes in the smooth muscle cells of these peripheral arteries also occur over a similar period of time. Cells which would normally be pericytes, intermediate cells, or smooth muscle cells with a synthetic phenotype become hypertrophied and have an increased concentration of myofilaments and dense bodies and thus show ultrastructural features typical of differentiated smooth muscle cells with a contractile phenotype. ${ }^{3}$ Many of these changes are an acceleration of the normal pattern of development. In both the normal and pulmonary hypertensive lung, the development of the sympathetic innervation seems to occur in parallel with an increase in the amount of smooth muscle in peripheral arteries and with an: increase in the differentiation of that muscle. Sym pathetic nerves may be exerting a long term trophie effect on the vascular muscle cells. Certainly i culture, vascular smooth muscle cells undergo aff accelerated maturation in the presence of sympath etic nerves and also show increased incorporation of protein in the presence of contractile agonists. ${ }^{54}$ o

In all the controls and children with pulmonar $\vec{\Phi}$ hypertension vasoactive intestinal peptide and somatostatin (presumed parasympathetic) an\& tachykinin and calcitonin gene related peptide (sens sory) immunoreactive nerve fibres were more spar sely distributed than the relatively dense, presumedp sympathetic innervation of the pulmonary vas $\frac{\mathrm{N}}{\mathrm{W}}$ culature. Previous studies showed both nerves and specific binding sites in the small muscular pulmono ary arteries of the adult lung that were immunoreac tive to vasoactive intestinal peptide. ${ }^{25}{ }^{26}$ In the presen $\overrightarrow{\hat{f}}$ study, at all ages vasoactive intestinal peptide fibres seemed most abundant in the small muscular arteries just proximal to the respiratory unit-arteries that can be considered as the resistance vessels of the lung Extensive innervation of these vessels suggests that the flow of blood into the respiratory unit and

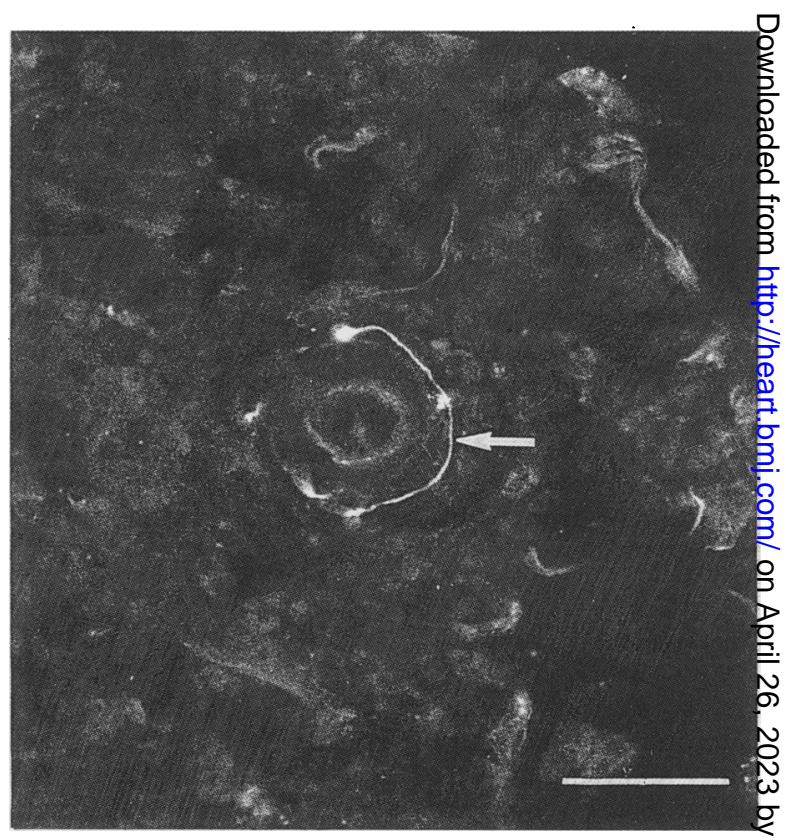

Fig 8 Photomicrograph showing fibres (arrow) that were immunoreactive to neuropeptide tyrosine running around the adventitial border of an alveolar duct artery in a two month? old patient with pulmonary hypertension. Scale bar = $50 \mu \mathrm{m}$. 
capillary bed is partly under neurogenic control.

Vasoactive intestinal peptide, ${ }^{25}{ }_{27}$ substance $P,{ }^{28}$ and calcitonin gene related peptide ${ }^{29}$ are all potent vasodilators and all have been shown to relax pulmonary arteries in man or other species. As with vasoactive intestinal peptide, specific binding sites for substance $\mathrm{P}^{30}$ and calcitonin gene related peptide ${ }^{31}$ have been localised to medial smooth muscle cells of human intrapulmonary arteries by in vitro autoradiography. Whether or not the action of the vasoactive peptides is endothelium-dependent is particularly important in the context of pulmonary hypertension because endothelial damage and denudation can be seen in the small muscular arteries of many pulmonary hypertensive children after the age of six months. ${ }^{3}$ Substance $P$ seems to require an intact endothelium ${ }^{28} 32$ to be effective whereas vasoactive intestinal peptide and calcitonin gene-related peptide seem to be less endothelium dependent. ${ }^{27} 29$ If in the children with pulmonary hypertension endothelial damage reduces the effectiveness of endothelial dependent vasodilator neuropeptides, this might explain why pulmonary hypertensive crises develop in some children but not others. All the patients with pulmonary hypertension had abnormally thick walled, prematurely innervated respiratory unit arteries. Numerous other vasoactive substances acting on and produced by the endothelium may be just as important. Studies on receptor localisation, density, and kinetics and on the interaction between vasoactive peptides, endothelium, and vascular smooth muscle in the immature lung are indicated.

The present study indicates that the vasoconstrictor peptide, neuropeptide tyrosine, is the predominant neuropeptide in the pulmonary circulation at all ages, in both the normal and pulmonary hypertensive lung. In infants with pulmonary hypertension, the premature innervation of peripheral, abnormally thick walled, pulmonary arteries may be important in the aetiology of pulmonary hypertensive crises-the vasoconstrictor episodes which characterise the postoperative course of many young children after intracardiac repair.

This work was supported by grants from the British Heart Foundation and the National Fund for Research into Crippling Diseases. SGH is supported by the British Heart Foundation.

\section{References}

1 Allen K, Haworth SG. Human postnatal pulmonary arterial remodelling: ultrastructural studies of smooth muscle cell and connective tissue maturation. Lab Invest 1988;58:702-9.
2 Allen K, Haworth S. Cytoskeletal features of immature pulmonary vascular smooth muscle cells and the influence of pulmonary hypertension on normal human development. J Pathol 1989;158:311-7.

3 Haworth S, Hall S, Burford B, Allen K, Mills A. The effect of pulmonary hypertensive congenital heart disease on the post-natal remodelling of the pulmonary vasculature [Abstract]. J Am Coll Cardiol 1988;11 (suppl A):135A.

4 Wharton J, Haworth SG, Polak J. Postnatal development of the innervation and paraganglia in the porcine pulmonary arterial bed. J Pathol 1988;154:19-27.

5 Chamley J, Campbell GR, Burnstock G. Dedifferentiation, redifferentiation and bundle formation of smooth muscle cells in tissue culture: influence of cell number and nerve fibres. J Embryol Exp Morphol 1974;32:297-323.

6 Amenta F, Cavalloti C, Ferrante F, Tonelli F. Cholinergic innervation of the human pulmonary circulation. Acta Anat (Basel) 1983;117:58-64.

7 Kay K. Pulmonary vasculature and nerves. Comparative morphological features of the pulmonary vasculature in mammals. Am Rev Respir Dis 1983;128:S53-7.

8 Dey R, Shannon W, Said S. Localisation of VIPimmunoreactive nerves in airways and pulmonary vessels of dogs, cats and human subjects. Cell Tissue Res 1981;220:231-8.

9 Hua X-Y, Theodorsson-Northeim E, Brodin E, Lundberg J, Hokfelt $T$. Multiple tachykinins (neurokinin $A$, neuropeptide $K$ and substance $P$ ) in capsaicinsensitive sensory neurones in the guinea pig and rat. Regul Pept 1985;13:1-19.

10 Wharton J, Gulbenkian S, Mulderry P, et al. Capsaicin induces a depletion of calcitonin gene-related peptide (CGRP)-immunoreactive nerves in the cardiovascular system of the guinea pig and rat. J Auton Nerv Syst 1986;16:289-309.

11 Sheppard MN, Polak JM, Allen JM, Bloom SR. Neuropeptide tyrosine (NPY): a newly discovered peptide is present in the mammalian respiratory tract. Thorax 1984;39:326-30.

12 Lundberg J, Martling C-R, Hökfelt T. Airways, oral cavity and salivary glands: classical transmitters and peptides in sensory and autonomic motor neurones. In: Bjorkland A, Höfelt T, Owman C, eds. Handbook of chemical neuroanatomy, vol 6. Amsterdam: Elsevier, 1988:391-444.

13 Wharton J, Gulbenkian S, Merighi A, et al. Immunohistochemical and ultrastructural localization of peptide-containing nerves and myocardial cells in the human atrial appendage. Cell Tissue Res 1988;254:155-66.

14 Gulbenkian S, Wharton J, Polak J. The visualisation of cardiovascular innervation in the guinea pig using an antiserum to protein gene product 9.5 (PGP 9.5). $J$ Auton Nerv Syst 1987;18:235-47.

15 Wiedenmann B, Franke $W$. Identification and localization of synaptophysin, an integral membrane glycoprotein of $\mathrm{Mr} 38,000$ characteristic of presynaptic vesicles. Cell 1985;41:1017-28.

16 Gulbenkian S, Wharton J, Hacker G, Varndell I, Bloom S, Polak J. Co-localisation of neuropeptide tyrosine 
(NPY) and its C-terminal flanking peptide (CPON). Peptides 1985;6:1237-43.

17 Haworth SG, Hislop AA. Pulmonary vascular development: normal values of peripheral vascular structure. Am J Cardiol 1983;52:578-83.

18 Haworth SG, Hall SM, Chew M, Allen K. Thinning of fetal pulmonary arterial wall and postnatal remodelling: ultrastructural studies on the respiratory unit arteries. Virchows Arch [A] 1987;411:161-71.

19 Burnstock G. Neuropeptides as trophic factors. In: Polak JM, Lindenlaub, E, eds. Systemic role of regulatory peptides. Stuttgart: FK Schattauer Verlag, 1982:423-40.

20 Keatinge $\mathbb{W}$, Torrie $C$. Action of sympathetic nerves on inner and outer muscle of sheep carotid artery, and effect of pressure on nerve distribution. J Physiol (Lond) 1976;257:699-712.

21 Pernow J, Saria A, Lundberg J. Mechanisms underlying pre- and postjunctional effects of neuropeptide $\mathrm{Y}$ in sympathetic vascular control. Acta Physiol Scand 1986;126:239-49.

22 Ekblad E, Edvinsson L, Wahlestedt C, Uddman R, Hakanson R, Sundler F. Neuropeptide Y co-exists and co-operates with noradrenaline in perivascular nerve fibres. Reg Pept 1984;8:225-35.

23 Wahlestedt C, Edvinsson L, Ekblad E, Hakanson R. Neuropeptide $\mathrm{Y}$ potentiated noradrenaline-evoked vasoconstriction: mode of action. J Pharmacol Exp Ther 1985;234:735-41.

24 Geisterfer A, Peach M, Owens G. Angiotensin II induces hypertrophy, not hyperplasia, of cultured rat aortic smooth muscle cells. Circ Res 1988;62: 749-56.
25 Barnes PJ, Cadieux A, Carstairs JR, Greenberg B, $\subseteq$ Polak JM, Rhoden K. Vasoactive intestinal peptide in $\overrightarrow{\vec{F}}$ bovine pulmonary artery: localisation, function and $\stackrel{\mathcal{F}}{+}$ receptor autoradiography. $\mathrm{Br} J$ Pharmacol 1986;89: $157-62$.

26 Carstairs J, Barnes PJ. Visualisation of vasoactive $\frac{\bar{\omega}}{\frac{\omega}{5}}$

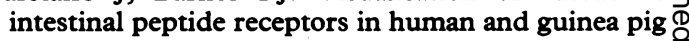
lung. J Pharmacol Exp Ther 1986;239:249-55.

27 Greenberg B, Rhoden K, Barnes P. Relaxant effects of $क$ vasoactive intestinal peptide and histidine isoleucine $\overrightarrow{0}$ in human and bovine pulmonary arteries. Blood Vessels 1987;24:45-50.

28 Tanaka $D$, Grunstein $M$. Vasoactive effects of substance $\mathrm{P}$ on isolated rabbit pulmonary artery. J Appl Physiol 1985;58:1291-7.

29 McCormack D, Mak J, Barnes P. Calcitonin gene- $N$ related peptide (CGRP) causes non-endothelial $\omega$ dependent relaxation of human pulmonary arteries $\mathcal{E}$ and veins [Abstract]. Am Rev Respir Dis 1988; 응 137:372.

30 Carstairs J, Barnes P. Autoradiographic mapping of $\vec{Z}$ substance $P$ receptors in lung. Eur $J$ Pharmacolo 1986;127:295-6.

31 Mak J, Barnes P. Autoradiographic localization of 3 calcitonin gene-related peptide (CGRP) binding sites $\mathbb{\complement}$ in human and guinea pig lung. Peptides 1988;9: 957-63.

32 D'Orleans-Juste P, Dion S, Drapeau G, Regoli D. Different receptors are involved in the endotheliummediated relaxation and smooth muscle contraction of the rabbit pulmonary artery in response to substance $\mathrm{P}$ and related neurokinins. Eur J Pharmacolo 1985;125:37-44. 